Article

\title{
Optimization of Phytoremediation of Nickel by Alocasia puber Using Response Surface Methodology
}

\author{
Najaa Syuhada Mohamad Thani ${ }^{1}$, Rozidaini Mohd Ghazi ${ }^{1, * \mathbb{C} \text {, }}$ \\ Ikarastika Rahayu Abdul Wahab ${ }^{2}{ }^{\mathbb{D}}$, Mohamad Faiz Mohd Amin ${ }^{1}$, Zulhazman Hamzah ${ }^{1}$ and \\ Nik Raihan Nik Yusoff 1,3 (D) \\ 1 Faculty of Earth Science, Universiti Malaysia Kelantan, Jeli 17600, Malaysia; \\ najaa_syuhada@yahoo.com (N.S.M.T.); mohamadfaiz@umk.edu.my (M.F.M.A.); \\ zulhazman@umk.edu.my (Z.H.); nraihan@umk.edu.my (N.R.N.Y.) \\ 2 Faculty of Agro-Based Industry, Universiti Malaysia Kelantan, Jeli 17600, Malaysia; ikarastika@umk.edu.my \\ 3 Green Design and Manufacture Research Group, Center of Excellence Geopolymer and Green \\ Technology (CEGeoGTech), Universiti Malaysia Perlis, Kangar 01000, Malaysia \\ * Correspondence: rozidaini@umk.edu.my; Tel.: +60-9947-7354
}

Received: 17 July 2020; Accepted: 23 September 2020; Published: 27 September 2020

check for updates

\begin{abstract}
The contamination of water by heavy metals is a worldwide environmental problem. Phytoremediation and constructed wetlands have become increasingly popular as more sustainable and environmentally friendly techniques of removing heavy metals from the wastewater. This study, therefore, investigated the phytoremediation of nickel by Alocasia puber (A. puber) in a constructed wetlands $(\mathrm{CW})$ microcosm. This study identified the optimum conditions for nickel (Ni) removal from wastewater using response surface methodology (RSM) with central composite design (CCD). Two operational variables were assessed: exposure time and initial Ni concentration. The optimum conditions for the maximum removal of $\mathrm{Ni}$ from water were an exposure time of 10 days and $99.76 \mathrm{mg} / \mathrm{L}$ initial Ni concentration. The results indicated that $95.6 \%$ removal was achieved under the optimized conditions, with a high correlation coefficient $\left(R^{2}=0.97\right)$ between the statistical model and the experimental data. Field emission scanning electron microscopy images showed anatomical changes in the A. puber samples due to $\mathrm{Ni}$ exposure, and transmission electron microscopy images revealed some internal damages in the $A$. puber, but visual Ni toxicity symptoms, such as necrosis and chlorosis, were not observed in the A. puber. This study demonstrated that A. puber planted in a constructed wetland microcosm was able to remediate wastewater contaminated with $\mathrm{Ni}$.
\end{abstract}

Keywords: constructed wetlands microcosm; phytoremediation; water treatment; Ni removal; Alocasia puber

\section{Introduction}

The presence of heavy metals in water causes considerable concern, since they are toxic to human beings, animals, and plants. Heavy metals, even when present in low concentrations in water, pose a serious risk to human health. Heavy metals like lead $(\mathrm{Pb})$, copper $(\mathrm{Cu})$, chromium $(\mathrm{Cr})$, zinc $(\mathrm{Zn})$, silver $(\mathrm{Ag})$, mercury $(\mathrm{Hg})$, nickel $(\mathrm{Ni})$, cadmium $(\mathrm{Cd})$, arsenic $(\mathrm{Ar})$, and tin $(\mathrm{Sn})$ must be removed from wastewater in order to meet increasingly stringent environmental quality standards [1,2], as well as to mitigate their non-biodegradability and consequent persistence [3].

There are many methods (whether chemical or physical) to adsorb heavy metals from the environment, including chemical precipitation, ion exchange, membrane filtration, and electrochemical treatment technologies [4]. However, the economic feasibility of said methods varies. The adsorption of heavy metals by adsorption technology is also a good alternative, and it is used in the treatment of 
wastewater and soil. To compare the methods, the adsorbent substances, the cost, and effectiveness must be considered. Activated carbon is a highly effective substance to adsorb heavy metals from wastewaters, but the cost of the commercial activated carbon is high. Consequently, the use of activated carbon from agricultural byproducts can also be used as an alternative method to remove toxic pollutants in wastewaters [5-7]. However, the production yield of activated carbon from agricultural byproducts is low. Another alternative is to use plants in remediation, also known as phytoremediation. Phytoremediation is a cost-effective technology for environmental cleaning, involving the planting of native plants in a polluted area [8]. Although this method has not been widely utilized, it could be effectively used at contaminated sites to treat pollutants, especially heavy metals, at a substantially lower operating cost [9].

Constructed wetlands (CWs) are an alternative and promising technology for water or wastewater treatment and pollution mitigation. It belongs to the category of natural treatment systems. The main principle is to exploit natural materials (e.g., gravel, sand, and plants) and naturally occurring processes under controlled conditions for water treatment purposes. Constructed wetlands have been characterized as an environmentally friendly and sustainable technology that provides economic, ecological, technical, and societal benefits. It is an emergent technology which can be effectively used for domestic, municipal and industrial wastewater treatments, as well as for sludge dewatering and drying [10]. This system yields a good retention of heavy metals. Previous studies have reported that aquatic plants or macrophytes have the ability to accumulate and sequester metals, both above-ground (shoot) and below-ground (root) in non-metabolically active tissues into less harmful forms [11]. The CW system is capable of removing contaminants like metals, organic and inorganic matters, nutrients, and pathogens from various wastewater sources, making it a simple and low-cost domestic water treatment system [12]. Its simplicity relative to other wastewater technology may result in reduced operation and maintenance requirements [13]. In addition, mechanical components and external energy supply are not necessary for CW systems [14].

Araceae, which is one of the mesophytic plant families in tropical Asia, is the fourth largest family of monocotyledons after orchids [15]. Araceae has the capability of being a "hyperaccumulator" of heavy metals and organic compounds, and can efficiently remove said compounds from water. Colocasia esculanta, Alocasia macrorrhiza, and Pistia stratiotes have also shown a potential for removing pollutants from different wastewaters [11,16-19].

Among the Araceae family in general and the Alocasia genus in particular, Alocasia macrorrhiza (A. macrorrhiza) is the most studied for its phytoremediation potential. According to Zhu and Xia [20], A. macrorrhiza has been used to increase phytoremediation potential by co-cropping with Sedum alfredii. The findings were subsequently supported by Qiu et al. [21], who reported that co-planting these two plants was more effective than mono-planting in reducing total $\mathrm{Zn}$ and diethylenetriaminepentaacetic acid (DTPA)-extractable $\mathrm{Zn}, \mathrm{Cd}$, and Cu concentrations in sewage sludge. Therefore, the environmental risks associated with heavy metals and benzo[ $\alpha]$ pyrene in sewage sludge were reduced. Moreover, this plant demonstrates the ability to translocate $\mathrm{Pb}$ and $\mathrm{Cu}$ to its harvestable parts when cultivated on soil collected from selected dumpsites [22].

A study on pond water purification effects showed that $A$. macrorrhiza could remove $\mathrm{NH}_{3}-\mathrm{N}$ effectively with a $99.11 \%$ removal rate of $\mathrm{NH}_{3}-\mathrm{N}$, while net removal rates reached $70 \%$ after 3 days of treatment. Additionally, the plant can remove chemical oxygen demand (COD) and $\mathrm{Cr}$ at $82.98 \%$ and $73.30 \%$, respectively, with and without aeration conditions. These findings indicated that $A$. macrorrhiza is a good candidate for treating water pollution [23]. A. macrorrhiza was also recommended as a wetland plant by Zhu and Xia [20], based on their study that showed its strong adaptation to the environment. Its purifying ability and rates were above $90 \%$ for $\mathrm{COD}$, and the $\mathrm{Cr}$ concentration was between 150-180 mg/L. Meanwhile, its sister species, Alocasia odora, was identified as having a high content of oxalic acid, and it can be used to clean lead-contaminated soil [24].

Due to the limited scientific study on the use of Alocasia puber (A. puber) for heavy metal remediation, this study investigates its potential as a new plant for phytoremediation. A. puber, which is only 
found on Peninsular Malaysia and in West Java, occurs in abundance in Kelantan, particularly in Bukit Bakar and the Lojing Highlands. Constructed wetland microcosms planted with $A$. puber were used to treat water contaminated with various $\mathrm{Ni}$ concentrations at different exposure times. This study aims to maximise the removal efficiency of Ni from water using response surface methodology (RSM) through a central composite design (CCD), by optimising heavy metal concentration and exposure time. Among all of the preliminary experiments conducted on heavy metals (including $\mathrm{Cr}, \mathrm{Cd}, \mathrm{Ni}, \mathrm{Cu}$, and $\mathrm{Zn}$ ), Ni was selected as a potential heavy metal to be removed using the CW systems, due to its maximum removal potential, as reported in a previous study by Mohamad Thani et al. [25].

\section{Materials and Methods}

\subsection{Preparation of Synthetic Ni Wastewater}

Synthetic wastewater containing $\mathrm{Ni}(1000 \mathrm{mg} / \mathrm{L})$ was prepared by dissolving $\mathrm{Ni}\left(\mathrm{NO}_{3}\right)_{2}$ (Bendosen, Shah Alam, Selangor) in distilled water. This concentration was diluted based on the desired concentration for the experiment $(5,52.5$, and $100 \mathrm{mg} / \mathrm{L})$.

\subsection{Experimental Design}

The experimental design for the present study was adopted and modified from Klomjek [26]. A reactor was developed to mimic a CW microcosm by using a transparent, rectangular, polypropylene basin $(30 \mathrm{~cm} \times 18.5 \mathrm{~cm} \times 18 \mathrm{~cm})$. The effluent was collected through a $3 \mathrm{~cm}$ diameter outlet at the base of the reactor. The microcosm consisted of three layers, as shown in Figure 1. The bottom layer contains $10 \mathrm{~cm}$ of gravel $(10-20 \mathrm{~mm})$. The middle layer contains $5 \mathrm{~cm}$ of gravel $(1-5 \mathrm{~mm})$, and the top layer contains $10 \mathrm{~cm}$ of soil with gravel $(0.2-0.5 \mathrm{~mm})$, without the supplementation of nutrient or fertilizer. Soil, sand, and gravels are traditional substrates used for CWs, due to their abundance, low cost, and retention of pollutants [27].

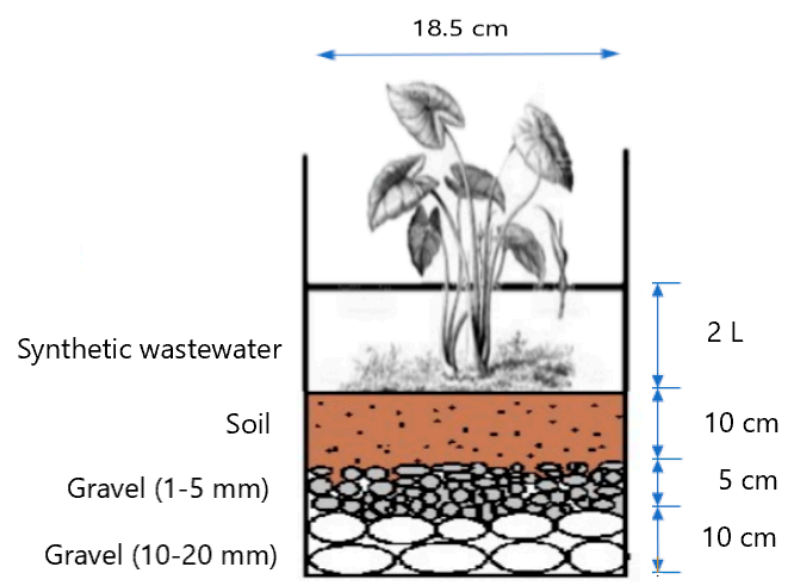

Figure 1. Experimental set up for a constructed wetland (CW) microcosm.

A. puber was collected from Bukit Bakar Forest Eco Park, Kelantan, and then transplanted at the centre top layer of the CW microcosm [28]. Four CW microcosms were assembled and acclimatised for 2 weeks prior to conducting the experiments. Each of the four CWs had individually planted $A$. puber to engender a significant plant root effect on the wastewater treatment. A control condition microcosm used distilled water (vs. synthetic Ni wastewater).

Synthetic Ni wastewater (2 L) with a known concentration of $5 \mathrm{mg} / \mathrm{L}$ was added to each $\mathrm{CW}$ microcosm on top of the substrate; the water levels were maintained at the upper soil layer to ensure sub-surface flow (SSF) and allowed to infiltrate each system [29]. All microcosms were wrapped with aluminium foil to eliminate sunlight penetration and the consequent photodegradation of the compounds. Microcosms were kept under greenhouse-like conditions, with a temperature variation 
between $23^{\circ} \mathrm{C}$ and $35^{\circ} \mathrm{C}$. The $\mathrm{CW}$ microcosm systems were designed to operate in batches without running flow during the tests, having only a tap (outlet) at the base for wastewater effluent collection. The collection was taken on days 2,7 , and 12 . These systems were repeatedly set up the initial Ni concentration of $52.5 \mathrm{mg} / \mathrm{L}$ and $100 \mathrm{mg} / \mathrm{L}$ where the effluent of the wastewater was collected after a given exposure time, as shown in Table 1. The systems operated in 12-day cycles from December 2017 to February 2018. The signs of toxicity were observed and recorded after each 12-day cycle.

Table 1. Value of initial Ni concentration and exposure time.

\begin{tabular}{ccc}
\hline Initial Concentration of $\mathbf{N i}(\mathbf{m g} / \mathbf{L})$ & Exposure Time (days) & Volume of Effluent Collected $(\mathbf{m L})$ \\
\hline \multirow{2}{*}{5.0} & 2 & 100 \\
& 7 & 100 \\
& 12 & 100 \\
52.5 & 2 & 100 \\
& 7 & 100 \\
& 12 & 100 \\
100.0 & 2 & 100 \\
& 7 & 100 \\
\hline
\end{tabular}

\subsection{Translocation Factor}

The A. puber used for the phytoremediation was collected at the end of the experiment. The samples were then rinsed thoroughly with running tap water, followed by distilled water to remove impurities. Filtered paper was used to eliminate excess moisture. The plants were then separated into leaves, stems, and roots. Approximately $0.5 \mathrm{~g}$ of each sample was added to $10 \mathrm{~mL}$ of $\mathrm{HNO}_{3}(65 \%)$ (Merck, Kenilworth, NJ, USA) for acid digestion. The concentration of heavy metals in the plant samples were analysed using an atomic absorption spectrophotometer (AAS) [30].

The translocation factor indicates phytoremediation efficiency, which is determined by using Equation (1):

$$
\text { Translocation Factor }(\mathrm{TF})=\frac{\text { C shoot }}{\text { C root }}
$$

\subsection{Response Surface Methodology (RSM)}

CCD was applied in this study for the purpose of data analysis using Design Expert Software Version 6.0.7. (Stat-Ease Inc., Minneapolis, MN, USA). RSM was used to determine the variables for the optimisation process, in order to optimise the variables and their responses [31].

The independent factors in this study were exposure time (days) and Ni concentrations. The percentage of Ni removal $(\mathrm{mg} / \mathrm{L})$ indicated the treatment response. A total of 13 experiments were conducted by testing the two said factors. Each factor was composed of three levels, and hence, a quadratic model was most suitable to be used in this study, as demonstrated in Equation (2):

$$
Y=\beta_{0}+\sum_{i=1}^{k} \beta_{i} X_{i}+\sum_{i=1}^{k} \beta_{i i} X_{i}^{2}+\sum_{i<j}^{k} \sum_{j}^{k} \beta_{i j} X_{i} X_{j}+\ldots+e
$$

The results were analysed statistically by using the analysis of variance (ANOVA). The factors were considered at three levels: low (-1), central (0), and high (+1). CCD and RSM were applied to predict the relationship between exposure time $(\mathrm{d})$ and initial concentration of $\mathrm{Ni}(\mathrm{mg} / \mathrm{L})$, as well as their corresponding response, the percentage removal of heavy metals (dependent variable) [31]. Different exposure times $(2,7$, and 12 days) and initial Ni concentrations $(5.0,52.5$, and $100.0 \mathrm{mg} / \mathrm{L})$ were tested in the CW microcosm system. 


\subsection{Toxicity Effects Towards Plant Cells}

Both field emission scanning electron microscopy (FESEM) and transmission electron microscopy (TEM) were used to study the anatomical changes to plant tissue after Ni exposure. The effect of $\mathrm{Ni}$ on the leaves, stems, and root tissues was observed and compared with the control plant. A. puber was collected at the end of the experiment. A. puber samples were analysed using FESEM (Quanta FEG $450 \mathrm{Model}$ ). The plant samples were prepared via primary fixation using $3 \%$ glutaraldehyde in a $0.05 \mathrm{M}$ phosphate buffer for $90 \mathrm{~min}$, followed by a secondary fixation using $2 \%$ osmium tetroxide in a $0.01 \mathrm{M}$ sodium cacodylate buffer for $30 \mathrm{~min}$ [32]. The samples were then dehydrated through a series of acetone. Next, the samples were sputtered with gold particles, using a sputter coater in a vacuum condition and observed under a scanning electron microscope at an accelerating voltage of 12 (or $15 \mathrm{kV}$ ) to capture the images [33].

The toxicity of Ni towards the root was further studied in detail using a transmission electron microscopy (TEM). A. puber was collected at the end of the experiment. The Ni exposed root was compared with the control plant root. The root samples were cut into approximately $1 \mathrm{~mm}$ lengths prior to observation. Then, the samples were fixed in $4 \%$ glutaraldehyde and stored for 2 days at $4{ }^{\circ} \mathrm{C}$. The samples were then washed with a $0.1 \mathrm{M}$ sodium cacodylate buffer three times for $30 \mathrm{~min}$ each and post-fixed with $1 \%$ osmium tetroxide $\left(\mathrm{OsO}_{4}\right)$. Subsequently, the samples were washed again with a sodium cacodylate buffer. Later, the samples were dried in an ethanol series and fixed in Spurr epoxy resin. An ultramicrotome was used to obtain ultrathin sections of samples, which were then marked with uranyl acetate and basic lead citrate to be observed under TEM (LEO 912AB) [34].

\subsection{Determination of Ni Removal Efficiency}

Effluent from each CW microcosm was collected on days 2, 7, and 12, which contributed to the 12-day experimental cycle. Clean glass bottles were used to collect the effluent on each sampling day and stored in a refrigerator at $4{ }^{\circ} \mathrm{C}$. The removal of $\mathrm{Ni}$ from the synthetic wastewater was analysed using an atomic absorption spectrophotometer (AAS) [35]. Ni concentration was determined before and after each treatment process. Equation (3) was used to calculate the removal efficiency of Ni:

$$
\text { Ni Removal Efficiency }(\%)=\frac{C i-C f}{C i} \times 100
$$

\section{Results and Discussion}

\subsection{Optimization by RSM}

In this study, the RSM approach was used to optimize the parameters affecting Ni removal and attain the best system performance within a small number of experiments. The design matrix for the central composite design study was generated using two parameters, resulting in a total of 13 experiments. The interactions between the factors (exposure time and initial $\mathrm{Ni}$ concentration) and the percentage removal were determined using polynomial regression. A quadratic model was built to fit the results.

Experimental data for the percentage removal of Ni are shown in Table 2. Table 2 shows central composite design and experimental results, indicating the relationship between exposure time, Ni concentration, and the response to removing $\mathrm{Ni}$.

The two factors were measured at three levels: low $(-1)$, moderate $(0)$, and high $(+1)$. Different exposure time (days 2, 7, and 12) and initial concentration of $\mathrm{Ni}(5.0,52.5$, and $100.0 \mathrm{mg} / \mathrm{L}$ ) were applied in this study. The three-dimensional (3D) plots were designed based on the experimental results. The results of the interaction between two factors (exposure time and initial concentration of $\mathrm{Ni}$ ) on response (percentage removal of $\mathrm{Ni}$ ) was then analysed by using polynomial regression. As shown in Table 2, the predicted values fit well to the actual values. The predicted responses obtained from RSM were compared to the actual responses for confirmation of the predicted data. 
Table 2. Central composite design (CCD) and experimental results.

\begin{tabular}{|c|c|c|c|c|}
\hline \multirow{3}{*}{ Run } & \multirow{3}{*}{$\begin{array}{c}\text { Factor } 1 \\
\text { A: Exposure } \\
\text { Time (day) }\end{array}$} & \multirow{3}{*}{$\begin{array}{c}\text { Factor } 2 \\
\begin{array}{c}\text { B: Ni Conc } \\
(\mathrm{mg} / \mathrm{L})\end{array}\end{array}$} & \multicolumn{2}{|c|}{ Response } \\
\hline & & & \multicolumn{2}{|c|}{ Removal of Ni (\%) } \\
\hline & & & Actual Values & Predicted Values \\
\hline 1 & 2.00 & 5.00 & 89.59 & 89.60 \\
\hline 2 & 12.00 & 5.00 & 91.18 & 92.39 \\
\hline 3 & 2.00 & 100.00 & 82.12 & 81.13 \\
\hline 4 & 12.00 & 100.00 & 94.04 & 94.25 \\
\hline 5 & 2.00 & 52.50 & 87.64 & 88.62 \\
\hline 6 & 12.00 & 52.50 & 98.00 & 96.58 \\
\hline 7 & 7.00 & 5.00 & 98.32 & 97.11 \\
\hline 8 & 7.00 & 100.00 & 93.03 & 93.81 \\
\hline 9 & 7.00 & 52.50 & 98.44 & 98.72 \\
\hline 10 & 7.00 & 52.50 & 97.20 & 98.72 \\
\hline 11 & 7.00 & 52.50 & 98.64 & 98.72 \\
\hline 12 & 7.00 & 52.50 & 98.91 & 98.72 \\
\hline 13 & 7.00 & 52.50 & 99.96 & 98.72 \\
\hline
\end{tabular}

\subsection{Interpretation of Regression Analysis for Ni Removal}

Table 3 shows the results of analysis of variance (ANOVA) for the regression parameters, which are used to verify the capability of the proposed model, $R^{2}, R^{2}$ adj, $F$-values, and $p$-values.

Table 3. ANOVA of the quadratic model.

\begin{tabular}{|c|c|c|c|c|c|}
\hline Source & $\begin{array}{l}\text { Sum of } \\
\text { Squares }\end{array}$ & $\begin{array}{l}\text { Degree of } \\
\text { Freedom }\end{array}$ & Mean Square & $F$-Value & Prob $>F$ \\
\hline Model & 342.22 & 5 & 68.44 & 41.64 & $\begin{array}{c}<0.0001 \\
\text { (significant) }\end{array}$ \\
\hline $\mathrm{A}$ & 94.96 & 1 & 94.96 & 57.77 & 0.0001 \\
\hline B & 16.34 & 1 & 16.34 & 9.94 & 0.0161 \\
\hline $\mathrm{A}^{2}$ & 103.29 & 1 & 103.29 & 62.84 & $<0.0001$ \\
\hline $\mathrm{B}^{2}$ & 29.36 & 1 & 29.36 & 17.86 & 0.0039 \\
\hline $\mathrm{AB}$ & 26.68 & 1 & 26.68 & 16.23 & 0.0050 \\
\hline Residual & 11.51 & 7 & 1.64 & & \\
\hline Lack of fit & 7.58 & 3 & 2.53 & 2.57 & $\begin{array}{c}0.1918 \\
\text { (insignificant) }\end{array}$ \\
\hline$R^{2}$ & 0.97 & $R^{2}$ adj & 0.94 & & \\
\hline
\end{tabular}

The ANOVA results exhibited that the model was significant, with an $F$-value of 41.64. There was a $0.01 \%$ chance that the large "Model $F$-Value" occurred due to noise. A value of "Prob $>F$ " less than 0.0500 indicates that the model terms are significant, whereas a value greater than 0.1000 implies that the model terms are not significant. In this case, $A, B, B^{2}$, and $A B$ were significant model terms. The "Lack of Fit F-value" of 2.57 shows that there was a $19.18 \%$ probability that a "Lack of Fit $F$-value" this large occurred due to noise. The $R^{2}$ value was close to $1\left(R^{2}=0.97\right)$, and thus was in reasonable agreement with the adjusted $R^{-2}$ of 0.94 .

\subsection{Interactive Effect of Exposure Time and Initial Concentration of $\mathrm{Ni}$}

In order to understand the effects of independent variables and their interactions on Ni removal, both a 3D surface plot and contour plots were constructed, as shown in Figure 2. Specifically, Figure 2 shows the interactions between exposure time and initial concentration of Ni. The predicted optimization values were calculated using a second-order polynomial equation. The coordinates of the maximum point were calculated through the first deviation of the mathematical function, which described the response surface and equated it to zero [36]. Exposure time was set in a range, 
while the maximum initial $\mathrm{Ni}$ concentration was used to achieve the maximum percentage of $\mathrm{Ni}$ removal. The optimum condition for Ni removal was obtained with the initial Ni concentration of $99.76 \mathrm{mg} / \mathrm{L}$ at an exposure time of 10 days. The observed removal was as high as $95.60 \%$.

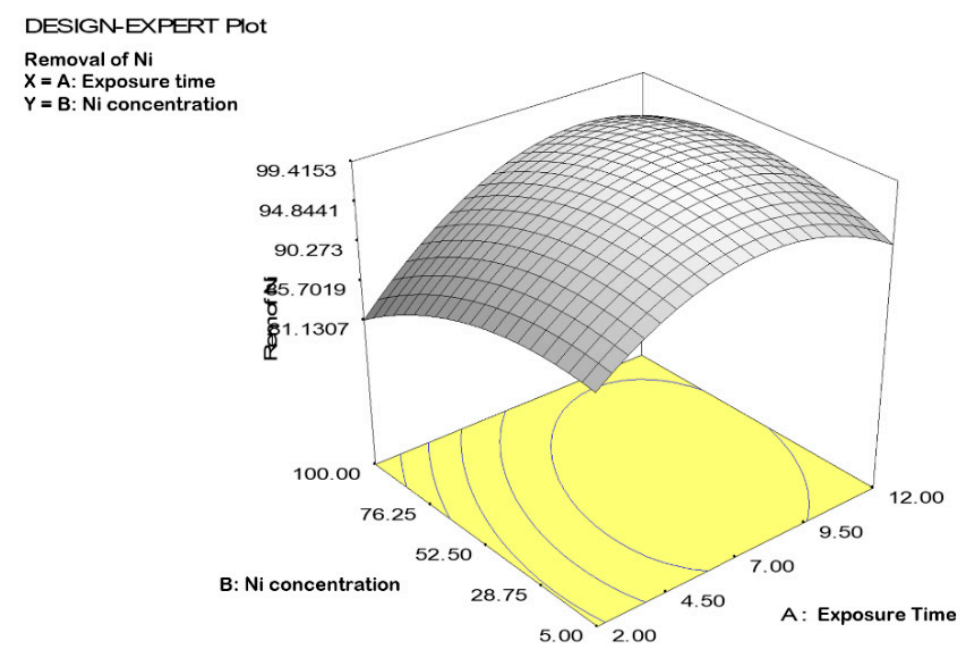

Figure 2. Optimization of Ni removal from water collected in the CW system.

The increase in exposure time and decrease in initial concentration of $\mathrm{Ni}$ resulted in an increased removal of Ni. Furthermore, increasing the time beyond 10 days did not significantly affect the percentage removal. Treatment with a longer exposure time and lower concentration resulted in a higher percentage removal of Ni. The findings showed that the response and percentage removal of $\mathrm{Ni}$ were highly influenced by the exposure time and initial concentration of Ni. At an early exposure time, the active sites for the media and plant surface adsorption were still emptied. With the increasing concentration of $\mathrm{Ni}$, the number of metal ions also increased, which affected Ni removal.

As shown in Figure 2, the outcomes of this research have demonstrated that the percentage removal of Ni decreased when the initial Ni concentration was increased. At higher concentrations of heavy metals $(100 \mathrm{mg} / \mathrm{L})$, morphological signs, such as yellowing and chlorosis, occurred due to the metal toxicity in some parts of the plants [37]. This finding concurred with a study by Du et.al. [38], whereby heavy metal accumulation had a limit beyond which water hyacinth uptake could no longer increase with the contamination level. The reason for this remains unknown, and deserves further investigation. To speculate, water hyacinth may limit the uptake of these highly toxic heavy metals through the immobilization or activation of selective barriers in the plasma membrane $[39,40]$.

The decline in percentage removal at high $\mathrm{Ni}$ concentration was probably due to the increased number of metal ions at higher concentrations, while the active sites for the media and plant surface adsorption remained constant. Yadav et al. [41] stated that adequate adsorption sites were available for metal ion adsorption at lower initial ion concentrations. Therefore, the increase of percentage removal relies on the lower initial metal concentration, and decreases with an increased initial metal concentration. Mwanyika et al. [42] have reported that sedimentation is one of the processes involved in reducing heavy metals in CW. Nevertheless, chemical processes like precipitation, as well as co-precipitation, are necessary before sedimentation can occur.

In addition, Mashhor et al. [43] claimed that heavy metal removal in CW was influenced by settling and sedimentation, insoluble salt precipitation, and the binding of soil, sediments, and particulate. Meanwhile, Ohlendorf et al. [44] reported that the metal removal efficacy in the CW system was dependent on the initial concentration and mass loading rates.

Generally, metal removal will be high at a higher exposure time. This is contributed by the longer exposure time between plants in the reactor with the contaminants, hence producing better degradation rates [45]. Stottmeister et al. [46] stated that the contaminant-plant root contact duration (exposure time) influenced the ability of the plant to remove and breakdown the contaminants. 
Dhir and Srivastava [47] discovered that the ability of helophytes to accumulate heavy metals was affected by heavy metal concentration and time, and they observed that the most significant increase was after 2 days of heavy metal exposure. Thus, metal removal efficacy will initially increase with increasing retention time and concentration.

\subsection{Translocation Factor}

A translocation factor (TF) was calculated to assess the translocation of accumulated Ni from root to shoots (stem and leaves). Table 4 shows the TF of Ni in A. puber. Generally, the TF values were less than 1 for Ni. TF values of less than 1 show low metal translocation to shoots, which reflects $A$. puber's ability to be a well-balanced metal accumulation and translocation plant [48].

Table 4. The translocation factor (TF) of $\mathrm{Ni}$ in A. puber.

\begin{tabular}{ccc}
\hline \multirow{2}{*}{ Element } & \multicolumn{2}{c}{ Translocation Factor } \\
\cline { 2 - 3 } & Stems/Roots & Leaves/Roots \\
\hline $\mathrm{Ni}$ & 0.17 & 0.11 \\
\hline
\end{tabular}

The present study showed that the accumulation factor for $\mathrm{Ni}$ was high in roots relative to stems (or leaves), thereby confirming the significance of roots as a heavy metal accumulator, as corroborated by Yadav et al. [49]. Accumulation by root is deemed the quickest method to remove heavy metals. Surface adsorption consists of physical and chemical processes, such as chelation, ion exchange, and the chemical precipitation of heavy metals [50]. The root system offers a large surface area for the accumulation of water and nutrients essential for growth, along with other, non-essential pollutants [51].

Metal translocation is the most commonly reported mechanism of phytoextraction, but it is certainly not the only process that transports metal into plants. Rhizofiltration, which is usually detected in aquatic and wetland plants, also contributes to the containment, immobilization, and accumulation of metals into root structures. Enzymes in the root zone can also cause the metals to precipitate onto the root surfaces [37]. In this study, rhizofiltration is believed to be a mechanism in the root system of $A$. puber responsible for the accumulation of metals onto the root surfaces. This process depends on the capability of plant roots to uptake and isolate metal ions [52]. Rhizofiltration also refers to the concentration of pollutants around the root system, as they settle out of the dissolved phase [53].

This finding concurs with earlier studies that use different plant species. Al-Farraj et al. [54], for example, studied the ability of Ochradenus baccatus as a phytoremediator, and found that the TF was less than 1 for $\mathrm{Cd}, \mathrm{Zn}, \mathrm{Cu}$, and $\mathrm{Pb}$. In a different study by Al-Farraj et al. [55], Cd, Cu, Pb, and the TF were less than 1 when Rhazya stricta was used. Additionally, Vandecasteele et al. [56] also discovered that the highest accumulation for $\mathrm{Cu}, \mathrm{Cr}, \mathrm{Pb}, \mathrm{Fe}, \mathrm{Mn}$, and $\mathrm{Ni}$ were in the roots of plants. Those results are in accordance with Gupta and Sinha [57], who found that $\mathrm{Fe}, \mathrm{Zn}, \mathrm{Cr}, \mathrm{Mn}, \mathrm{Cu}, \mathrm{Pb}, \mathrm{Ni}$, and $\mathrm{Cd}$ accumulation were higher in roots of Sesamum indicum relative to their shoots.

\subsection{FESEM Analysis}

Anatomical changes in $A$. puber, as a result of the phytoremediation of $\mathrm{Ni}$, were identified in the leaves, stems, and roots of the plants harvested at the end of the experiment. The changes were identified using field emission scanning electron microscopy (FESEM).

Figure 3 shows the FESEM images of the surface section of leaves of the control and Ni exposure, respectively. The leaf sample exposed to Ni showed morphological and anatomical changes. In addition, samples exposed to Ni (Figure 3b) showed slight changes in the foliar structures relative to the control (Figure 3a). 


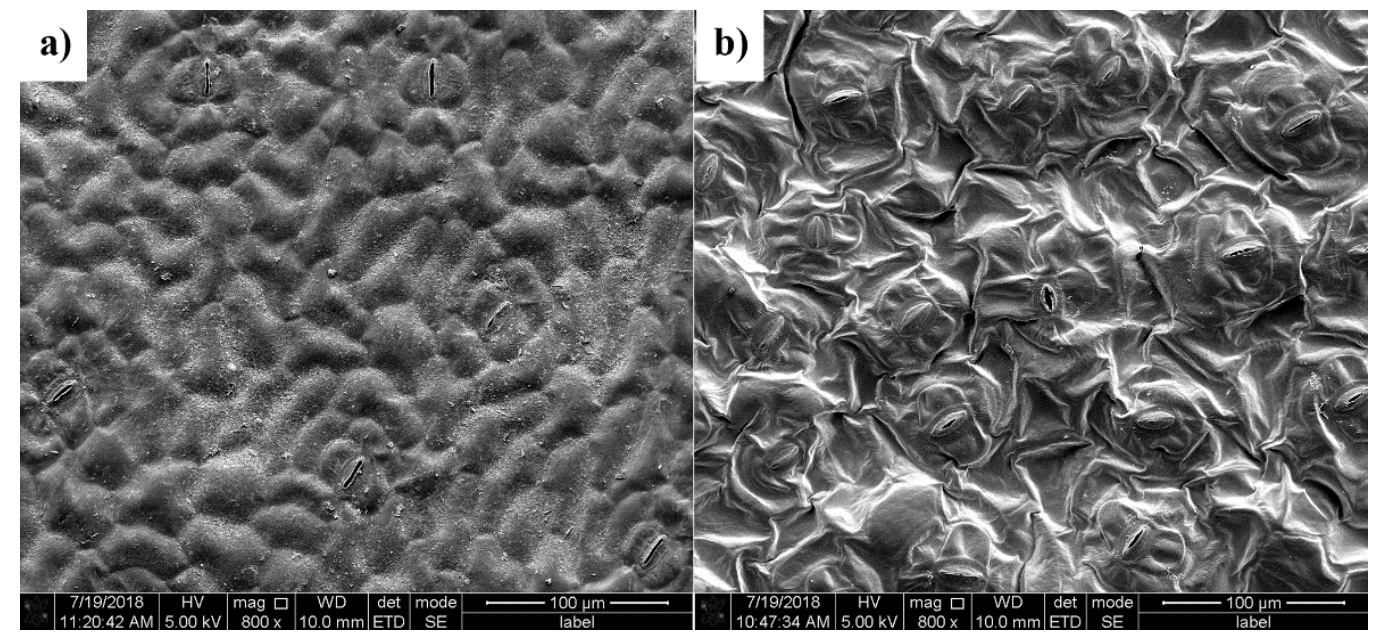

Figure 3. Field emission scanning electron microscopy (FESEM) micrograph of the surface leaves: (a) control; (b) Ni exposure.

Symptoms of toxicity have been observed in some plant species as a result of metal uptake and accumulation at high concentration, causing structural and ultrastructural changes that alter their development and physiology [58]. The FESEM analysis shows the accumulation of Ni within the root, stem, and leaf.

Figure 4a shows FESEM images of the cross-section of stem (control). It shows clearer parts of the stem, while the Ni-loaded plant sample demonstrates morphological changes in the tissues and formed deep holes visible on the stem (Figure 4b).

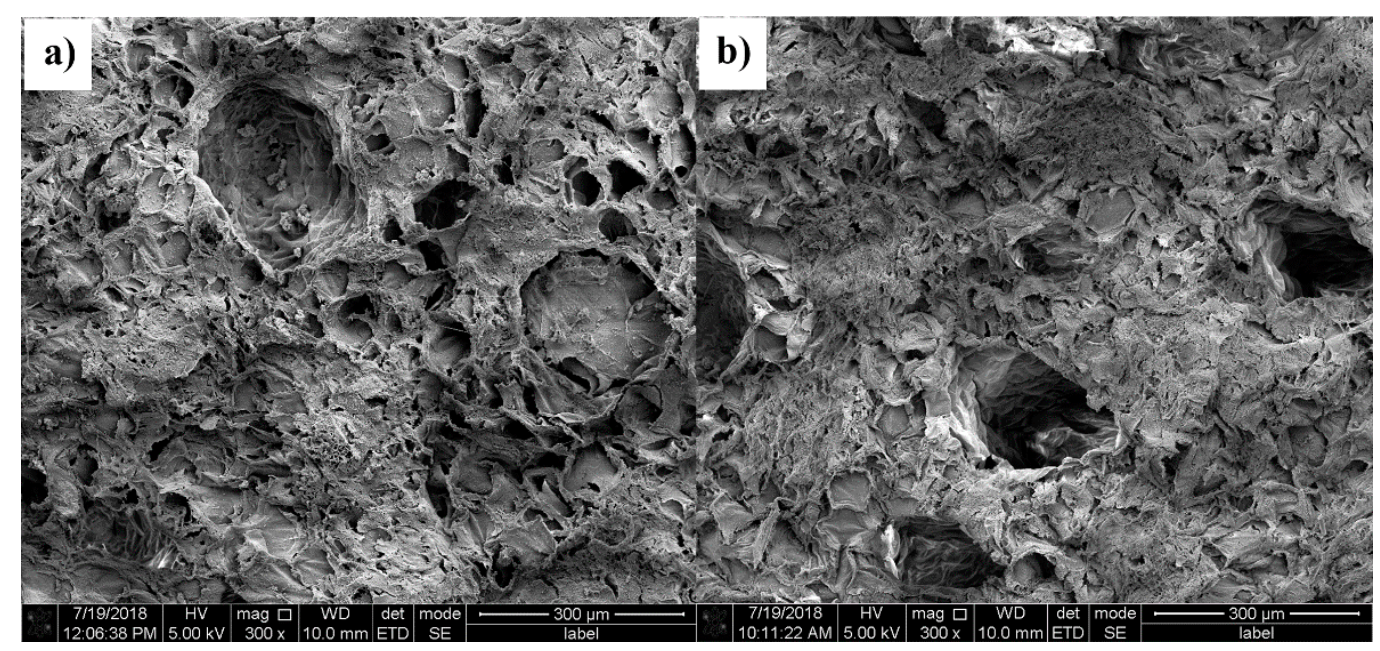

Figure 4. FESEM micrograph of cross-section stem: (a) control; (b) Ni exposure.

This morphological change is likely due to the oxidation process in the plant. At higher concentration levels, $\mathrm{Ni}$ can cause several toxicities in plant tissue, where it affects the physiological modification in the plant species. $\mathrm{Ni}$, which is a transition metal, can cause oxidative stress in plant tissue, and as a non-redox active metal, possesses the ability to indirectly inflict oxidative stress via multiple mechanisms [59]. Exposure to heavy metals triggers a wide range of physiological and biochemical alterations, and plants must develop or adopt a series of strategies that allow them to cope with the negative consequences of heavy metal toxicity [60]

Given that, the cross-section of the root samples in Figure 5 shows thickened cell walls in Ni-loaded samples (Figure 5b) relative to the control sample (Figure 5a), where the cell wall of the vascular bundles was thinner. The scanning electron micrographs of the control sample showed rigid cell walls, 
whereas in the Ni-loaded root, a thickening of the cell wall occurred. This observation indicates that there was a blockage in the uptake of toxic pollutants into the inner core, which contain storage and conducting cells [61,62] for the plant loaded with Ni.

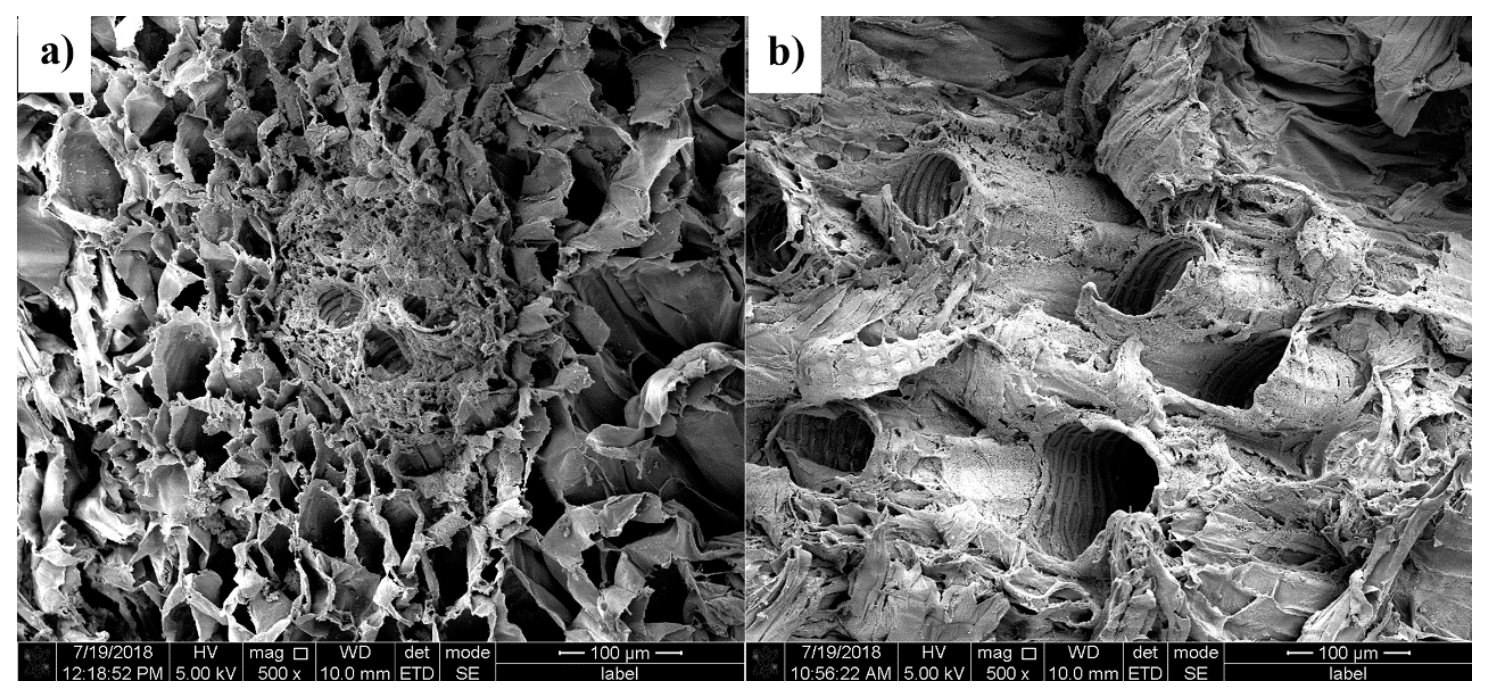

Figure 5. FESEM micrograph of cross-section root: (a) control; (b) Ni exposure.

The FESEM images of control and Ni-loaded samples of root surface are shown in Figure 6. As seen in Figure 6, the control plant roots (Figure 6a) were protected with numerous, long root hairs, whereas the root sample exposed to Ni (Figure 6b) possessed fewer and shorter root hairs.

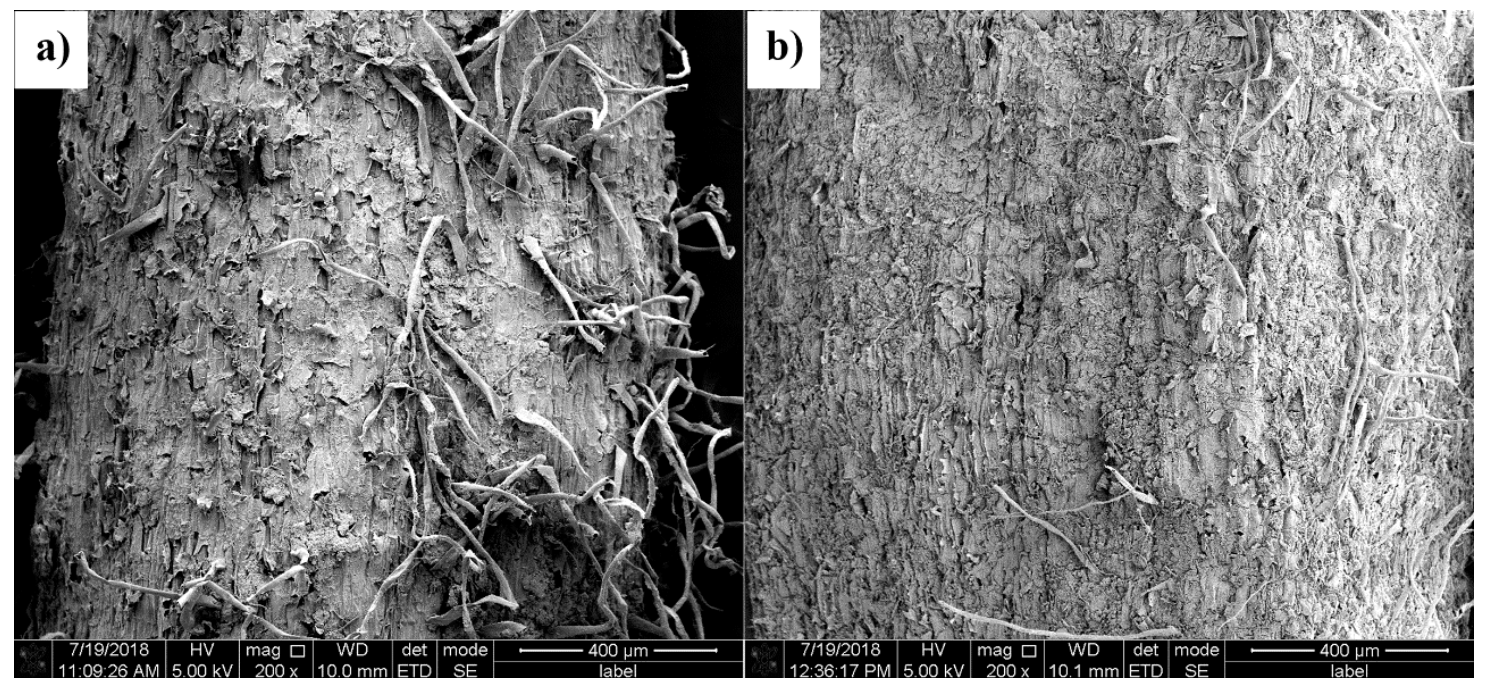

Figure 6. FESEM micrograph of surface root: (a) control; (b) Ni exposure.

The reduction in number and length of root hairs in the treated samples suggests that the plant restricted contaminant uptake by adopting the root hair-based strategy. Indeed, Balasubramaniyam and Harvey [62] stated that this move was practical, because it prevents the absorption of contaminants from the root hair into the main root. Therefore, the increase in root hair death is beneficial for the plant.

In the roots with $\mathrm{Ni}$ exposure, the uptake of toxic contaminants into the inner core, which contains conducting and storage cells, was blocked by the thickening of the plant cell walls. Metal ions can enter the roots by extracellular (apoplastic) or intracellular (symplastic) pathways. The apoplastic network is the continuous network of cell walls and extracellular spaces in plants where substances can pass through without having to go into the cell itself [63]. Rogers and Campbell [61] explained that the thickening process would alter the cell wall in a way that will make the cell wall an apoplastic 
network, impermeable to water; this reduces transfer, thus restricting cell expansion. The reduction in the number and length of root hairs in the treated root sample in Figure $6 \mathrm{~b}$ suggests that the plant restricted contaminant uptake by adopting the root hair-based strategy. In conclusion, high $\mathrm{Ni}$ concentrations in A. puber causes structural changes in roots, stems, and leaves, and alters their morphological characteristics.

\subsection{Transmission Electron Microscopy (TEM) Analysis}

The results obtained in the present study show that the root of $A$. puber contained the highest amount of heavy metals, and hence was selected for the analysis using TEM after the optimisation process. Piechalak et al. [64] reported that heavy metals would first attach to roots, since they provide a principal pathway for the penetration of metal ions. Growth is the most recognizable morphological parameter of plants undergoing metal stress, where the root growth is commonly the most affected. Furthermore, slow growth will result in low crop production if it occurs in cultivated plants [65].

Figure 7 illustrates the ultrastructural observations on the root cells of the control and Ni-loaded samples of $A$. puber. It was observed that the control cells were mostly healthy and without obvious damage (Figure 7a). The root cells exposed to Ni, in contrast, showed some ultrastructural alterations. The symptoms seen in these cells included distorted structures (Figure 7b). There was also a notable decrease in mitochondrial numbers and a significant expansion in their cristae (Figure $7 \mathrm{~b}$ ) relative to the root cells of the control sample in Figure 7a. In addition, Figure $7 \mathrm{~b}$ also shows the presence of electronic-dense granules in the cytoplasm as a symptom of Ni toxicity. The cell walls were visibly darker, and the precipitation of electron-dense granules was higher.

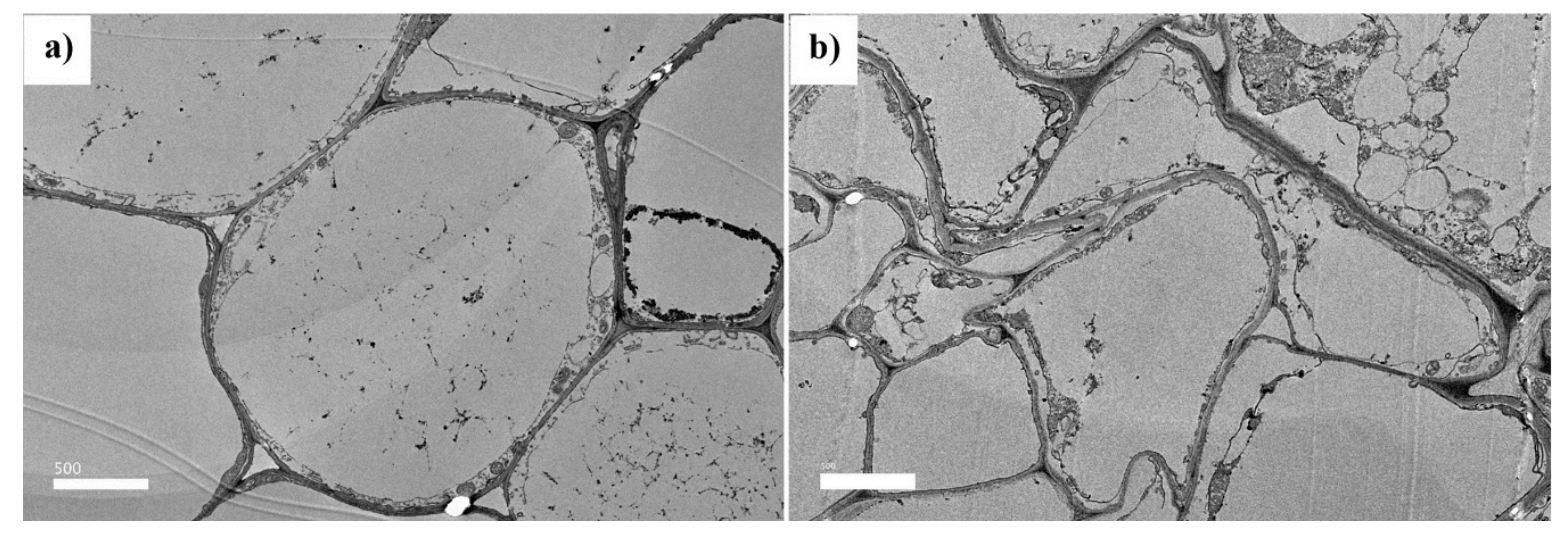

Figure 7. Transmission electron microscopy $($ TEM) micrograph (magnification $=\times 1500)$ of $(\mathbf{a})$ control tissue and (b) Ni-loaded tissue.

Previous studies have reported the presence of electron-dense granules in the cytoplasm, which appear to be a common occurrence in metal-stressed plants [66]. According to Lamas et al. [67], the formation of these granules in the cells exposed to Ni might be a purification pathway to avoid cell damage.

Hall [68] and Sinha et al. [69] agreed that intracellular changes are inevitable when there is a metal tolerance in plants. These changes include alterations in organelles, such as the cell wall, cytoplasm, and mitochondria.

Absorption, cellular localization, and the transport of metals like Ni determine the toxicity level in plants [70]. Based on the results of the present study, the roots of A. puber had the highest metal concentrations relative to the other tissues. Meanwhile, the TEM analysis exhibited that the root of A. puber contained small aggregates deposited in the cell wall fractions. Liu et al. [34] explained that the deposition pattern was the reason why $A$. puber roots were unable to smoothly transfer Ni into its aerial parts, hence limiting the apoplastic transport of this metal. 
There are several mechanisms that allow plants to keep growing well in environments with high metal content, including (a) plants having the ability to keep metal ions from entering into their cells, (b) plants having the ability to absorb metals in high concentrations and allocating them to certain tissues/organs, and (c) plants having mechanisms that allow metals to be detoxified so that they do not disrupt the plants' growth [65].

Nevertheless, there were no signs of adverse changes to the root of $A$. puber even after the high accumulation of $\mathrm{Ni}$ in the roots. This might be an adaptation that took place under stress, which in this case was caused by the high exposure to heavy metals. Thus, the root cells exposed to high $\mathrm{Ni}$ concentrations demonstrated an effective defence mechanism. It can be concluded that $A$. puber is a suitable plant for the phytoremediation of heavy metals in contaminated wastewater.

\section{Conclusions}

The optimum conditions for the maximum removal of $\mathrm{Ni}$ from water were an exposure time of 10 days and a $99.76 \mathrm{mg} / \mathrm{L}$ initial Ni concentration. The results indicated that $95.6 \%$ removal could be achieved under the optimized conditions. The present study has proven that $A$. puber is a suitable plant for the phytoremediation of $\mathrm{Ni}$, specifically in its roots, as shown by the TF value of $<1$. The plant still managed to survive in adverse conditions, even though there were signs of Ni toxicity when A. puber samples were analysed using FESEM and TEM methods. The clotted Ni deposits observed in the plant roots via TEM were probably a sign of adaptation and detoxification mechanisms by the A. puber and the above-ground plant parts. Therefore, A. puber is recommended for the removal of Ni from contaminated water. This study demonstrated that $A$. puber planted in constructed wetland microcosms was able to remediate wastewater contaminated with $\mathrm{Ni}$. Information obtained from this study can be used for the application of pilot-scale constructed wetland systems.

Author Contributions: Conceptualization, R.M.G. and N.S.M.T.; methodology, R.M.G.; M.F.M.A. and Z.H.; software, R.M.G.; validation, R.M.G., I.R.A.W. and N.R.N.Y.; formal analysis, N.S.M.T.; investigation, N.S.M.T.; resources, R.M.G. and M.F.M.A.; data curation, R.M.G. and N.S.M.T.; writing-original draft preparation, N.S.M.T. and R.M.G.; writing-review and editing, R.M.G., I.R.A.W. and N.R.N.Y.; supervision, R.M.G., I.R.A.W., M.F.M.A., and Z.H.; project administration, R.M.G.; funding acquisition, R.M.G. All authors have read and agreed to the published version of the manuscript.

Funding: This research was funded by Ministry of Higher Education Malaysia (MOHE), grant number R/FRGS/08.00/00266A/001/2016/000372.

Acknowledgments: The authors would like to acknowledge the Ministry of Higher Education Malaysia (MOHE) and Universiti Malaysia Kelantan (UMK) for funding the project through Fundamental Research Grant Scheme (R/FRGS/08.00/00266A/001/2016/000372).

Conflicts of Interest: The authors declare no conflict of interest.

\section{List of Notations}

$\begin{array}{ll}Y & \text { is the response } \\ X i, X j & \text { are the factors } \\ \beta 0 & \text { is the established coefficient } \\ \beta j, \beta j j \text { and } \beta i j & \text { are the interaction coefficients of linear-, quadratic-, and second-order terms } \\ k & \text { is the number of analysed parameters } \\ e & \text { is the error } \\ C i & \text { is the initial concentrations of Ni } \\ C f & \text { is the final concentrations of Ni } \\ C \text { shoot } & \text { is the concentration of Ni in the shoots of A.puber (stems or leaves) } \\ C \text { root } & \text { is the Ni concentration in the root of } A \text {. puber } \\ R^{2} & \text { is the correlation coefficient } \\ F \text {-values } & \text { are the ratio between-groups and within-groups of variances }\end{array}$




\section{References}

1. Bailey, S.E.; Olin, T.J.; Bricka, R.; Adrian, D. A review of potentially low-cost sorbents for heavy metals. Water Res. 1999, 33, 2469-2479. [CrossRef]

2. Aziz, H.A.; Adlan, M.N.; Ariffin, K.S. Heavy metals (Cd, Pb, Zn, Ni, Cu and Cr(III)) removal from water in Malaysia: Post treatment by high quality limestone. Bioresour. Technol. 2008, 99, 1578-1583. [CrossRef] [PubMed]

3. Dacera, D.D.M.; Babel, S. Removal of heavy metals from contaminated sewage sludge using Aspergillus niger fermented raw liquid from pineapple wastes. Bioresour. Technol. 2008, 99, 1682-1689. [CrossRef]

4. Fu, F.; Wang, Q. Removal of heavy metal ions from wastewaters: A review. J. Environ. Manag. 2011, 92, 407-418. [CrossRef]

5. Sairan, N.S.; Subki, N.S.; Nik Yusoff, N.R. Removal of Pb(II), Fe(II) and Zn(II) using activated carbon produced from foxtail palm fruit chemically activated by $\mathrm{KOH}$ and H3PO4. J. Trop. Resour. Sustain. Sci. 2019, 7, 19-22.

6. Sulaiman, M.A.; Shamsuddin, M.S.; Yusoff, N.R.N.; Subki, N.S. Microstructure of CuO assisted activated carbon adsorbent from rubber wood sawdust produced by mechanochemical processing. Solid. State Phenom. 2017, 264, 215-219. [CrossRef]

7. Xiang, V.M.; Ghazi, R.M. Adsorption of methylene blue from aqueous solution using palm kernel shell activated carbon. In Proceedings of the AIP Conference Proceedings, Kelantan, Malaysia, 18-19 August 2018; Volume 2068, p. 020038.

8. Chehregani, A.K.; Noori, M.; Yazdi, H.L. Phytoremediation of heavy metal polluted soils: Screening for new accumulator plants in Angouranmine (Iran) and evaluation of removalability. Ecotoxicol. Environ. Saf 2009, 72, 1349-1353. [CrossRef]

9. Maiti, R.K.; Pinero, J.L.H.; Oreja, J.A.G.; Santiago, D.L. Plant based bioremediation and mechanisms of heavy metal tolerance of plants: A review. Proc. Indian Natl. Sci. Acad. 2004, 70, 1-12.

10. Stefanakis, A.I. Constructed Wetlands: Description and benefits of an eco-tech water treatment system. In Impact of Water Pollution on Human Health and Environmental Sustainability; McKeown, E., Bugyi, G., Eds.; IGI Global: Hershey, PA, USA, 2016; pp. 283-305.

11. Madera, C.; Peña-Salamanca, E.J.; Pena, M.R.; Rousseau, D.P.L.; Lens, P.N.L. Phytoremediation of Landfill Leachate withColocasia esculenta, Gynerum sagittatumandHeliconia psittacorumin Constructed Wetlands. Int. J. Phytoremediation 2015, 17, 16-24. [CrossRef]

12. Rai, U.; Tripathi, R.; Singh, N.; Upadhyay, A.; Dwivedi, S.; Shukla, M.; Mallick, S.; Singh, S.; Nautiyal, C. Constructed wetland as an ecotechnological tool for pollution treatment for conservation of Ganga river. Bioresour. Technol. 2013, 148, 535-541. [CrossRef]

13. Ranieri, E.; Gikas, P.; Tchobanoglous, G. BTEX removal in pilot-scale horizontal subsurface flow constructed wetlands. DESALINATION Water Treat. 2013, 51, 3032-3039. [CrossRef]

14. Abou-Elela, S.I.; Golinielli, G.; Abou-Taleb, E.M.; Hellal, M.S. Municipal wastewater treatment in horizontal and vertical flows constructed wetlands. Ecol. Eng. 2013, 61, 460-468. [CrossRef]

15. Mashhor, M.; Boyce, P.C.; Sofiman, A.O.; Baharuddin, S. The Araceae of Peninsular Malaysia; Universiti Sains Malaysia Publisher: Pulau Pinang, Malaysia, 2012; pp. 18-22.

16. Chan, K.M.; Mohd Ghazi, R. Phytoremediation of Chromium(VI) using Colocasia esculenta in Laboratory Scale Constructed Wetlands. J. Trop. Resour. Sustain. Sci. 2018, 6, 45-49.

17. Chavan, B.L.; Dhulap, V.P. Developing a Pilot Scale Angular Horizontal Subsurface Flow Constructed Wetland for Treatment of Sewage through Phytoremediation with Colocasia esculenta. Int. Res. J. Environ. Sci. 2013, 2, 6-14.

18. Mahmud, R.; Inoue, N.; Kasajima, S.-Y.; Shaheen, R. Assessment of potential indigenous plant species for the phytoremediation of arsenic-contaminated areas of Bangladesh. Int. J. Phytoremediation 2008, 10, 119-132. [CrossRef]

19. Khan, M.A.; Marwat, K.B.; Gul, B.; Wahid, F.; Khan, H.; Hashim, S. Pistia stratiotes L. (Araceae): Phytochemistry, Use in Medicines, Phytoremediation, Biogas and Management Options. Pak. J. Bot. 2014, 46, 851-860.

20. Zhu, Q.; Xia, H. Study on selection of new artificial wetland plant species. J. Hydrol. 2010, 3, 76-86.

21. Qiu, J.R.; Guo, X.F.; Cai, Q.Y.; Liu, W.; Zhang, M.W.; Wei, Z.B.; Wu, Q.-T. Phytotreatment of Sewage Sludge Contaminated by Heavy Metals and Pahs by Co-Planting Sedum Alfredii and Alocasia Marorrhiza. Int. J. Phytoremediation 2013, 16, 1-13. [CrossRef] 
22. Asaolu, S.S.; Awokunmi, E.E.; Ajayi, O.O.; Adebayo, O.A. Phytoremediation potential of Alocasia microrrhiza grown on soil collected from selected dumpsites in Ekiti State, Nigeria. E3S Web Conf. 2013, 1, 13003.

23. Wang, G. Study on the Pond Water Purification Effect by Pistia stratiotes and Alocasia macrorrhiza. Water Purif. Technol. 2008, 27, 46-49.

24. Rathore, K.S.; Sunilkumar, G.; Campbell, L.M. Cotton Plant with Seed Specific Reduction in Gossypol. U.S. Patent No. 20070199098, 24 March 2015.

25. Thani, N.S.M.; Ghazi, R.M.; Amin, M.F.M.; Hamzah, Z. Phytoremediaton of heavy metals from wastewater by constructed wetland microcosm planted with alocasia puber. J. Teknol. 2019, 81, 17-23. [CrossRef]

26. Klomjek, P. Swine wastewater treatment using vertical subsurface flow constructed wetland planted with Napier grass. Sustain. Environ. Res. 2016, 26, 217-223. [CrossRef]

27. Yang, Y.; Zhao, Y.; Liu, R.; Morgan, D. Global development of various emerged substrates utilized in constructed wetlands. Bioresour. Technol. 2018, 261, 441-452. [CrossRef] [PubMed]

28. Chavan, B.L.; Dhulap, V.P. Optimization of pollutant concentration in sewage treatment using constructed wetland through phytoremediation. Int. J. Adv. Res. Sci. Eng. Technol. 2012, 1, 1-16.

29. Boto, M.; Almeida, C.M.R.; Mucha, A.P. Potential of constructed wetlands for removal of antibiotics from saline aquaculture effluents. Water 2016, 8, 465. [CrossRef]

30. Mustapha, H.I.; van Bruggen, J.J.A.; Lens, P.N.L. Fate of heavy metals in vertical subsurface flow constructed wetlands treating secondary treated petroleum refinery wastewater in Kaduna, Nigeria. Treat. Pet. Refin. Wastewater Constr. Wetl. 2018, 20, 147-172. [CrossRef]

31. Mojiri, A.; Aziz, H.A.; Zahed, M.; Aziz, S.Q.; Selamat, M.R.B. Phytoremediation of Heavy Metals from Urban Waste Leachate by Southern Cattail (Typha domingensis). Int. J. Sci. Res. Environ. Sci. 2013, 1, 63-70. [CrossRef]

32. Sandalio, L.; Dalurzo, H.C.; Gómez, M.; Romero-Puertas, M.C.; Del Río, L. Cadmium-induced changes in the growth and oxidative metabolism of pea plants. J. Exp. Bot. 2001, 52, 2115-2126. [CrossRef]

33. Pathan, A.; Bond, J.; Gaskin, R. Sample preparation for SEM of plant surfaces. Mater. Today 2010, $12,32-43$. [CrossRef]

34. Liu, D.; Li, S.; Islam, E.; Chen, J.R.; Wu, J.S.; Ye, Z.Q.; Peng, D.L.; Yan, W.B.; Lu, K.P. Lead accumulation and tolerance of Moso bamboo (Phyllostachys pubescens) seedlings: Applications of phytoremediation*. J. Zhejiang Univ. Sci. B 2015, 16, 123-130. [CrossRef]

35. Al-Baldawi, I.A.; Abdullah, S.R.S.; Abu Hasan, H.; Suja, F.; Anuar, N.; Mushrifah, I. Optimized conditions for phytoremediation of diesel by Scirpus grossus in horizontal subsurface flow constructed wetlands (HSFCWs) using response surface methodology. J. Environ. Manag. 2014, 140, 152-159. [CrossRef] [PubMed]

36. Bezerra, M.A.; Santelli, R.E.; Oliveira, E.P.; Villar, L.S.; Escaleira, L.A. Review: Response Surface Methodology (RSM) as a Tool for Optimization in Analytical Chemistry. Talanta 2008, 76, 965-977. [CrossRef] [PubMed]

37. Mishra, V.K.; Tripathi, B. Accumulation of chromium and zinc from aqueous solutions using water hyacinth (Eichhornia crassipes). J. Hazard. Mater. 2009, 164, 1059-1063. [CrossRef] [PubMed]

38. Du, Y.; Wu, Q.; Kong, D.; Shi, Y.; Huang, X.; Luo, D.; Chen, Z.; Xiao, T.; Leung, J.Y. Accumulation and translocation of heavy metals in water hyacinth: Maximising the use of green resources to remediate sites impacted by e-waste recycling activities. Ecol. Indic. 2020, 115, 106384. [CrossRef]

39. Mishra, S.; Dubey, R.S. Heavy metal uptake and detoxification mechanisms in plants. Int. J. Agric. Res. 2006, $1,122-141$.

40. Antoniadis, V.; Levizou, E.; Shaheen, S.M.; Ok, Y.S.; Sebastian, A.; Baum, C.; Prasad, M.N.; Wenzel, W.W.; Rinklebe, J. Trace elements in the soil-plant interface: Phytoavailability, translocation, and phytoremediation-A review. Earth-Sci. Rev. 2017, 171, 621-645. [CrossRef]

41. Yadav, A.K.; Kumar, N.; Sreekrishnan, T.; Satya, S.; Bishnoi, N.R. Removal of chromium and nickel from aqueous solution in constructed wetland: Mass balance, adsorption-desorption and FTIR study. Chem. Eng. J. 2010, 160, 122-128. [CrossRef]

42. Mwanyika, F.T.; Ogendi, G.M.; Kipkemboi, J.K. Removal of heavy metals from wastewater by a constructed wetland system at Egerton University, Kenya. IOSR J. Environ. Sci. Toxicol. Food Technol. 2016, 10, 15-20.

43. Mashhor, M.; Lim, P.E.; Shutes, R.B.E. Constructed Wetlands: Design, Management and Education; Universiti Sains Malaysia Publisher: Pulau Pinang, Malaysia, 2002.

44. Knight, R.L.; Kadlec, R.H.; Ohlendorf, H.M. The use of treatment wetlands for petroleum industry effluents. Environ. Sci. Technol. 1999, 33, 973-980. [CrossRef] 
45. Thakur, C.; Mall, I.D.; Srivastava, V.C. Effect of hydraulic retention time and filling time on simultaneous biodegradation of phenol, resorcinol and catechol in a sequencing batch reactor. Arch. Environ. Prot. 2013, 39, 69-80. [CrossRef]

46. Stottmeister, U.; Wiesner, A.; Kuschk, P.; Kappelmeyer, U.; Kastner, M.; Bederski, O.; Müller, R.; Moormann, H. Effects of plants and microorganisms in constructed wetlands for wastewater treatment. Biotechnol. Adv. 2003, 22, 93-117. [CrossRef] [PubMed]

47. Dhir, B.; Srivastava, S. Heavy metal removal from a multi-metal solution and wastewater by Salvinia natans. Ecol. Eng. 2011, 37, 893-896. [CrossRef]

48. Maiti, S.K.; Jaiswal, S. Bioaccumulation and translocation of metals in the natural vegetation growing on fly ash lagoons: A field study from Santaldih thermal power plant, West Bengal, India. Environ. Monit. Assess. 2007, 136, 355-370. [CrossRef] [PubMed]

49. Yadav, A.K.; Abbassi, R.; Kumar, N.; Satya, S.; Sreekrishnan, T.; Mishra, B. The removal of heavy metals in wetland microcosms: Effects of bed depth, plant species, and metal mobility. Chem. Eng. J. 2012, 211-212, 501-507. [CrossRef]

50. Dushenkov, V.; Kumar, P.B.A.N.; Motto, H.; Raskin, I. Rhizofiltration: The use of plants to remove heavy metals from aqueous streams. Environ. Sci. Technol. 1995, 29, 1239-1245. [CrossRef]

51. Ouyang, Y. Phytoremediation: Modeling plant uptake and contaminant transport in the soil-plant-atmosphere continuum. J. Hydrol. 2002, 266, 66-82. [CrossRef]

52. Dushenkov, S.; Kapulnik, Y. Phytoremediation of Toxic Metals Using Plants to Clean up the Environment; John Wiley \& Sons: Hoboken, NJ, USA, 1999; pp. 1-304.

53. Sharma, S.; Singh, B.; Manchanda, V.K. Phytoremediation: Role of terrestrial plants and aquatic macrophytes in the remediation of radionuclides and heavy metal contaminated soil and water. Environ. Sci. Pollut. Res. 2014, 22, 946-962. [CrossRef]

54. Al-Farraj, A.S.; Al-Otabi, T.G.; Al-Wabel, M.I. Accumulation coefficient and translocation factor of heavy metals through ochradenus baccatus plant grown on mining area at Mahad Ad'dahab, Saudi Arabia. Ecosyst. Sustain. Dev. VII 2009, 122, 459-468.

55. Al-Farraj, A.S.; Al-Wabel, M.I.; Al-Shahrani, T.S.; El-Maghraby, S.E.; Al-Sewailem, M.A.S. Accumulation coefficient and translocation factor of heavy metals through Rhazya stricta grown in the mining area of Mahad AD'Dahab, Saudi Arabia. Waste Manag. Environ. V 2010, 140, 325-336.

56. Vandecasteele, B.; Meers, E.; Vervaeke, P.; De Vos, B.; Quataert, P.; Tack, F.M.G. Growth and trace metal accumulation of two Salix clones on sediment-derived soils with increasing contamination levels. Chemosphere 2005, 58, 995-1002. [CrossRef]

57. Gupta, A.K.; Sinha, S. Chemical fractionation and heavy metal accumulation in the plant of Sesamum indicum (L.) var. T55 grown on soil amended with tannery sludge: Selection of single extractants. Chemosphere 2006, 64, 161-173. [CrossRef] [PubMed]

58. Han, F.X.; Sridhar, B.B.M.; Monts, D.L.; Su, Y. Phytoavailability and toxicity of trivalent and hexavalent chromium to Brassica juncea. New Phytol. 2004, 162, 489-499. [CrossRef]

59. Emamverdian, A.; Ding, Y.; Mokhberdoran, F.; Xie, Y. Heavy metal stress and some mechanisms of plant defense response. Sci. World J. 2015, 2015, 1-18. [CrossRef] [PubMed]

60. Singh, S.; Parihar, P.; Singh, R.; Singh, D.; Prasad, S.M. Heavy Metal tolerance in plants: Role of transcriptomics, proteomics, metabolomics, and ionomics. Front. Plant. Sci. 2016, 6, 6. [CrossRef]

61. Rogers, L.A.; Campbell, M.M. The genetic control of lignin deposition during plant growth and development. New Phytol. 2004, 164, 17-30. [CrossRef]

62. Balasubramaniyam, A.; Harvey, P.J. Scanning electron microscopic investigations of root structural modifications arising from growth in crude oil-contaminated sand. Environ. Sci. Pollut. Res. 2014, 21, 12651-12661. [CrossRef]

63. Salt, D.E.; Blaylock, M.; Kumar, N.P.; Dushenkov, V.; Ensley, B.D.; Chet, I.; Raskin, I. Phytoremediation: A novel strategy for the removal of toxic metals from the environment using plants. Nat. Biotechnol. 1995, 13, 468-474. [CrossRef]

64. Piechalak, A.; Tomaszewska, B.; Barałkiewicz, D.; Małecka, A. Accumulation and detoxification of lead ions in legumes. Phytochemistry 2002, 60, 153-162. [CrossRef]

65. Hamim, H.; Miftahudin, M.; Setyaningsih, L. Cellular and Ultrastructure Alteration of Plant Roots in Response to Metal Stress. In Plant Growth and Regulation-Alterations to Sustain Unfavorable Conditions; IntechOpen: London, UK, 2018. 
66. Jiang, W.S.; Liu, D.H.; Xu, P. Cd-induced system of defence in the garlic root meristematic cells. Boil. Plant. 2009, 53, 369-372. [CrossRef]

67. Einicker-Lamas, M.; Mezian, G.A.; Fernandes, T.B.; Silva, F.L.S.; Guerra, F.; Miranda, K.; Attias, M.; Oliveira, M.M. Euglena gracilis as a model for the study of $\mathrm{Cu} 2+$ and $\mathrm{Zn} 2+$ toxicity and accumulation in eukaryotic cells. Environ. Pollut. 2002, 120, 779-786. [CrossRef]

68. Hall, J.L. Cellular mechanisms for heavy metal detoxification and tolerance. J. Exp. Bot. 2002, 53, 1-11. [CrossRef] [PubMed]

69. Sinha, S.; Gupta, A.K.; Bhatt, K. Uptake and translocation of metals in fenugreek grown on soil amended with tannery sludge: Involvement of antioxidants. Ecotoxicol. Environ. Saf. 2007, 67, 267-277. [CrossRef] [PubMed]

70. Singh, R.P.; Tripathi, R.D.; Sinha, S.; Maheshwari, R.; Srivastava, H. Response of higher plants to lead contaminated environment. Chemosphere 1997, 34, 2467-2493. [CrossRef]

(C) 2020 by the authors. Licensee MDPI, Basel, Switzerland. This article is an open access article distributed under the terms and conditions of the Creative Commons Attribution (CC BY) license (http://creativecommons.org/licenses/by/4.0/). 